\title{
Stress, Allostatic Load, and Psychosis: One Step Forward in Research But Where to Go Next?
}

\author{
Błażej Misiak * \\ Department of Genetics, Wroclaw Medical University, Wroclaw, Poland
}

\section{OPEN ACCESS}

Edited by:

Stefan Borgwardt,

University of Basel, Switzerland

Reviewed by:

Zoltan Sarnyai

James Cook University, Australia

Joshua J. Chiappelli,

University of Maryland, Baltimore,

United States

*Correspondence:

Błażej Misiak

mblazej@interia.eu

Specialty section:

This article was submitted to

Schizophrenia,

a section of the journal

Frontiers in Psychiatry

Received: 27 November 2018

Accepted: 25 November 2019

Published: 09 January 2020

Citation:

Misiak B (2020) Stress, Allostatic

Load, and Psychosis: One Step

Forward in Research But

Where to Go Next?

Front. Psychiatry 10:937.

doi: 10.3389/fpsyt.2019.00937
Stress exposure leads to the activation of several biological mechanisms that have been termed allostasis. These processes enable adaptation to novel situations; however; their prolonged activation exerts systemic and detrimental effects called the allostatic load (AL). The AL concept represents one of useful paradigms to describe biological consequences of chronic stress that might lead to a number of disease outcomes. The AL index, which is a collective measure of cardiovascular, metabolic, neuroendocrine, and immune dysregulations associated with stress exposure, has been found to predict morbidity and mortality in non-clinical populations. Consequently, it has been proposed that the AL concept might be a useful framework to describe biological consequences of chronic stress exposure in patients with psychotic disorders. This perspective article is an overview of studies investigating the AL index and its clinical correlates in patients with psychotic disorders. These studies have consistently reported elevated $A L$ index in patients at the early and chronic course of psychosis. In addition, the AL index has been associated with a higher severity of positive and depressive symptoms, working memory impairments, and lower general functioning. The article provides some critical appraisal of studies in this field and indicates several future directions for investigating the $\mathrm{AL}$ concept in psychosis.

Keywords: schizophrenia, trauma, allostasis, glucocorticoid, hypothalamic-pituitary-adrenal axis

\section{INTRODUCTION}

Psychotic disorders represent complex phenotypes with imprecise diagnostic boundaries. Prevalence of psychotic disorders has been estimated at around 3\% and this group of mental disorders is perceived as one of most substantial causes of disability worldwide (1). There is a general consensus that the pathophysiology of psychosis is multidimensional with the involvement of several genetic factors, characterized by small effect size estimates, and environmental factors (2). Therefore, a paradigm shift toward implementation of models that might comprehensively capture biological alterations observed in psychosis is increasingly being recognized as a promising research perspective.

Accumulating evidence indicates that stress during critical windows of brain development might play an important role in the development of psychotic disorders (3). Approximately one third of patients with psychosis report a history of childhood trauma and this type of stressful experiences is 
a well-established risk factor of psychosis development $(4,5)$. Although exposure to early-life stress is neither necessary nor sufficient to cause psychosis, several studies indicate that a history of childhood adversities is related to a number of biological alterations observed in this group of patients [for review see (6)]. These alterations are represented by the hypothalamic-pituitary-adrenal (HPA) axis dysregulation, manifesting in elevated morning (7) and diurnal cortisol (8) levels, blunted cortisol awakening response (9), and attenuated cortisol response to stress (10). There are also studies showing lower levels of peripheral blood brain-derived neurotrophic factor (BDNF) (11), elevated levels of pro-inflammatory cytokines (12), more pronounced metabolic alterations (13), and altered DNA methylation profiles (14) in patients with psychosis and a history early-life traumatic stress. Patients with psychosis and self-reported childhood adversities present with unfavorable short- and long-term treatment and functional outcomes $(15,16)$. Finally, higher levels of stress biomarkers have been found to predict transition from ultra-high risk states to fully blown psychotic episode (17).

In light of several associations between stress exposure and biological alterations observed in psychosis, several models have been proposed to capture this complexity, including the reactive scope model (18), the adaptive calibration model (19), and the neural diathesis-stress model (20). Our group has also proposed that the allostatic load (AL) concept might be a useful paradigm since it provides a measurable construct (the AL index), summarizing various stress-related biological dysregulation (21). Afterwards, a number of studies investigated the AL index in patients with psychosis at various stages of illness. In this perspective article, I provide a brief overview of basic assumptions underlying the $\mathrm{AL}$ concept, review studies investigating the $\mathrm{AL}$ index in psychosis, and indicate future directions for studies investigating this paradigm in psychotic disorders.

\section{DEFINITIONS AND A BRIEF OVERVIEW OF THE ALLOSTATIC LOAD CONCEPT}

Homeostasis alterations driven by exposure to stress lead to the activation of several biological processes that have been collectively termed "allostasis" (22). These processes enable adaptation to the demands of unexpected situations and act via a number of mediators, including i.e., hormones, neurotransmitters, neurotrophins, oxidative stress, and immune-inflammatory markers (21). The adaptive nature of allostatic processes is disrupted in case of chronic stress and continuous arousal. Indeed, prolonged activation of allostasis exerts systemic and detrimental effects. This condition has been defined as the AL (23), while diseases related to chronic stress and the AL have been termed the allostatic overload (24). The central nervous system gateways for mediators of allostasis are mainly represented by prefrontal cortex, the amygdala, and the hippocampus (25). The AL index represents a cumulative score of biological dysregulations measured by neuroendocrine, immune, metabolic, and cardiovascular markers. This measure has been found to predict mortality and morbidity, better than traditional detection methods, in several non-psychiatric populations (26). To date, several operationalizations have been proposed to calculate the AL index. However, a consensus statement regarding the calculation of the AL index has yet to be developed.

\section{STUDIES ON THE ALLOSTATIC LOAD CONCEPT IN PSYCHOTIC DISORDERS}

A summary of studies investigating the AL index in patients with psychosis was provided in Table $\mathbf{1}$. To date, nine studies with overlapping samples of participants have investigated the AL index in patients with psychotic disorders $(28,32)$. Although various methods of calculating the AL index have been used, these studies have provided consistent evidence of elevated AL index in patients with schizophrenia (32-34) and first-episode psychosis (FEP) $(27,30,31,33)$. We also found similarly elevated AL index in patients with FEP and individuals at familial high risk of psychosis (FHR-P). The AL index has been found to decrease following antipsychotic treatment (27).

Higher AL index has been associated with more severe positive symptoms and functional impairment in some $(27,32$, 35 ) but not all studies $(30,31)$. In one study $(28)$, baseline AL index was investigated with respect to clinical outcomes at 6 and 12 months of observation in individuals at ultra-high risk of psychosis. The authors also found a positive correlation between the AL index and a severity of functional impairment after 6 months. Additionally, higher AL index predicted higher scores of manic symptoms. Our group investigated the association between the AL index, depressive symptoms, and stress coping styles in FEP patients (30). We found that patients with FEP were less likely to use active and task-focused coping compared to controls. Lower odds of using these coping styles, planning as well as positive reinterpretation and growth were related to higher AL index in FEP patients, but not in controls. Depressive symptomatology was associated with lower odds of using task-focused coping as well as positive reinterpretation and growth, and was related to higher $\mathrm{AL}$ index. In addition, depressive symptoms mediated the effects of task-focused coping as well as positive reinterpretation and growth on the AL index. Furthermore, we investigated whether the AL index might be related to cognitive impairment observed in patients with psychosis $(31,33)$. We found that higher $\mathrm{AL}$ index is associated with worse performance of attention (in patients with psychosis and FHR-P individuals) and semantic fluency (in patients with psychosis). This association appeared to be nonsignificant in healthy controls. Interestingly, no significant correlations between the AL index and perceived stress or life stressors were found in the groups of patients and controls (30, 32, 33).

The association between the AL index and cognitive impairment is supported by the findings from studies investigating neurostructural correlates of the $\mathrm{AL}$ index in 
TABLE 1 | A summary of studies investigating the allostatic load index in psychosis.

\begin{tabular}{|c|c|c|c|c|c|c|c|c|}
\hline \multirow[t]{2}{*}{ Study } & \multicolumn{2}{|c|}{ Patients } & \multicolumn{2}{|c|}{ Controls } & \multirow[t]{2}{*}{ Diagnoses } & \multirow[t]{2}{*}{ AL biomarkers } & \multirow{2}{*}{$\begin{array}{c}\text { Clinical } \\
\text { assessment } \\
\text { tools }\end{array}$} & \multirow[t]{2}{*}{ Main findings } \\
\hline & $n(M / F)$ & $\begin{array}{c}\text { Age } \\
(\text { mean } \pm \text { SD })\end{array}$ & $n$ (M/F) & $\begin{array}{l}\text { Age (mean } \\
\quad \pm \text { SD) }\end{array}$ & & & & \\
\hline $\begin{array}{l}\text { Berger } \\
\text { et al. ( } 27)\end{array}$ & $\begin{array}{l}\text { FEP: } 28 \\
(19 / 9) \\
\text { SCZ: } 28 \\
(15 / 13)\end{array}$ & $\begin{array}{l}\text { FEP: } 33.0 \pm 11.5 \\
\text { SCZ: } 40.1 \pm 10.1\end{array}$ & $\begin{array}{c}53 \\
(36 / 17)\end{array}$ & $36.3 \pm 11.5$ & $\begin{array}{l}\text { SCZ and } \\
\text { schizoaffective } \\
\text { disorder }\end{array}$ & $\begin{array}{l}\text { SBP, DBP, HR, } \\
\text { BMI, WHR, } \\
\text { creatine kinase, } \\
\text { insulin, glucose, } \\
\text { HbA1c, enRAGE, } \\
\text { TG, TC, LDL, } \\
\text { HDL, TNF- } \alpha \text {, IL- } \\
6 R \text {, CRP, E- } \\
\text { selectin, cortisol, } \\
\text { metanephrine, } \\
\text { normetanephrine, } \\
\text { and copeptin }\end{array}$ & $\begin{array}{l}\text { SCID, PANSS, } \\
\text { and GAF }\end{array}$ & $\begin{array}{l}\text { The AL index was significantly higher } \\
\text { in FEP and SCZ patients compared } \\
\text { to controls at baseline (with no } \\
\text { significant differences between FEP } \\
\text { and SCZ patients). The AL index } \\
\text { was associated with significantly } \\
\text { higher severity of positive symptoms } \\
\text { (PANSS) and functional impairment } \\
\text { (GAF, trend level significance). The } \\
\text { AL index significantly decreased } \\
\text { after } 6 \text { and } 12 \text { weeks of } \\
\text { antipsychotic treatment. }\end{array}$ \\
\hline $\begin{array}{l}\text { Berger } \\
\text { et al. (28) }\end{array}$ & $\begin{array}{c}106 \\
(36 / 70)\end{array}$ & $17.2 \pm 2.4$ & - & - & UHR & $\begin{array}{l}\text { SBP, DBP, HR, } \\
\text { cortisol, CRP, IL- } \\
6, \mathrm{IL}-12, \mathrm{TC}, \mathrm{TG} \text {, } \\
\text { and BMI }\end{array}$ & $\begin{array}{l}\text { CAARMS, } \\
\text { BPRS, SANS, } \\
\text { YMRS, MADRS, } \\
\text { SOFAS, GF-R, } \\
\text { GF-S, and CGI }\end{array}$ & $\begin{array}{l}\text { Higher baseline AL was associated } \\
\text { with poor social and occupational } \\
\text { functioning (SOFAS) and more } \\
\text { severe manic symptoms (YMRS) } \\
\text { after } 6 \text { months of observation. No } \\
\text { significant associations were found } \\
\text { after } 12 \text { months. }\end{array}$ \\
\hline $\begin{array}{l}\text { Chiappelli } \\
\text { et al. (29) }\end{array}$ & $44(28 / 16)$ & $32.7 \pm 12.6$ & $\begin{array}{c}33 \\
(19 / 14)\end{array}$ & $35.3 \pm 14.2$ & $\begin{array}{l}\text { SCZ and } \\
\text { schizoaffective } \\
\text { disorder }\end{array}$ & $\begin{array}{l}\text { SBP, DBP, HR, } \\
\text { BMI, WHR, HDL, } \\
\text { TC, HbA1c, CRP, } \\
\text { urine epinephrine } \\
\text { and } \\
\text { norepinephrine, } \\
\text { urine cortisol, and } \\
\text { blood DHEA }\end{array}$ & SCID and BPRS & $\begin{array}{l}\text { The AL index was significantly higher } \\
\text { in the group of patients compared to } \\
\text { controls. Whole brain average } \\
\text { cortical thickness was significantly } \\
\text { lower in the group of patients than in } \\
\text { controls. Once the AL index was } \\
\text { accounted, group differences in } \\
\text { cortical thickness appeared to be } \\
\text { insignificant. Elevated levels of CRP, } \\
\text { stress hormones, and cardiovascular } \\
\text { indices were related to cortical } \\
\text { thickness in patients. In the group of } \\
\text { controls, only CRP levels predicted } \\
\text { cortical thickness. }\end{array}$ \\
\hline $\begin{array}{l}\text { Misiak } \\
\text { et al. (30) }\end{array}$ & $36(20 / 16)$ & $27.5 \pm 7.4$ & $\begin{array}{c}31 \\
(12 / 19)\end{array}$ & $25.2 \pm 6.6$ & $\begin{array}{l}\text { FEP: SCZ, } \\
\text { schizophreniform } \\
\text { disorder, brief } \\
\text { psychotic } \\
\text { disorder, } \\
\text { schizoaffective } \\
\text { disorder, and } \\
\text { delusional } \\
\text { disorder }\end{array}$ & $\begin{array}{l}\text { SBP, DBP, BMl, } \\
\text { WHR, CRP, } \\
\text { fibrinogen, } \\
\text { albumin, glucose, } \\
\text { insulin, TC, LDL, } \\
\text { HDL, TG, cortisol, } \\
\text { and DHEA-S }\end{array}$ & $\begin{array}{l}\text { OPCRIT, } \\
\text { PANSS, SANS, } \\
\text { SAPS, HDRS, } \\
\text { YMRS, GAF, } \\
\text { SOFAS, COPE, } \\
\text { CISS, LTE, and } \\
\text { PSS }\end{array}$ & $\begin{array}{l}\text { The AL index was significantly higher } \\
\text { in FEP patients compared to } \\
\text { controls. Patients with FEP were } \\
\text { less likely to use active and task- } \\
\text { focused coping. Lower odds of } \\
\text { using these coping styles, planning } \\
\text { as well as positive reinterpretation, } \\
\text { and growth were related to higher } \\
\text { AL index in FEP patients, but not in } \\
\text { controls. } \\
\text { Depressive symptoms were } \\
\text { associated with lower likelihood of } \\
\text { using task-focused coping as well } \\
\text { as positive reinterpretation and } \\
\text { growth, and were related to higher } \\
\text { AL index. Depressive symptoms } \\
\text { mediated the effects of task-focused } \\
\text { coping as well as positive } \\
\text { reinterpretation and growth on the } \\
\text { AL index. }\end{array}$ \\
\hline $\begin{array}{l}\text { Misiak } \\
\text { et al. (31) }\end{array}$ & $40(21 / 19)$ & $27.6 \pm 7.4$ & $\begin{array}{c}35 \\
(14 / 21)\end{array}$ & $25.5 \pm 6.7$ & $\begin{array}{l}\text { FEP: SCZ, } \\
\text { schizophreniform } \\
\text { disorder, brief } \\
\text { psychotic } \\
\text { disorder, } \\
\text { schizoaffective }\end{array}$ & $\begin{array}{l}\text { SBP, DBP, BMl, } \\
\text { WHR, CRP, } \\
\text { fibrinogen, } \\
\text { albumin, glucose, } \\
\text { insulin, TC, LDL, }\end{array}$ & $\begin{array}{l}\text { OPCRIT, } \\
\text { PANSS, SANS, } \\
\text { SAPS, HDRS, } \\
\text { YMRS, RBANS, } \\
\text { GAF, SOFAS, } \\
\text { LTE, and PSS }\end{array}$ & $\begin{array}{l}\text { Elevated AL index was confirmed in } \\
\text { FEP patients compared to controls. } \\
\text { There was a significant negative } \\
\text { correlation between the AL index } \\
\text { and the digit span test score }\end{array}$ \\
\hline
\end{tabular}


TABLE 1 | Continued

\begin{tabular}{|c|c|c|c|c|c|c|c|c|}
\hline \multirow[t]{2}{*}{ Study } & \multicolumn{2}{|c|}{ Patients } & \multicolumn{2}{|c|}{ Controls } & \multirow[t]{2}{*}{ Diagnoses } & \multirow[t]{2}{*}{ AL biomarkers } & \multirow{2}{*}{$\begin{array}{c}\text { Clinical } \\
\text { assessment } \\
\text { tools }\end{array}$} & \multirow[t]{2}{*}{ Main findings } \\
\hline & $n(M / F)$ & $\begin{array}{c}\text { Age } \\
(\text { mean } \pm S D)\end{array}$ & $\mathrm{n}(\mathrm{M} / \mathrm{F})$ & $\begin{array}{l}\text { Age (mean } \\
\quad \pm \text { SD) }\end{array}$ & & & & \\
\hline & & & & & $\begin{array}{l}\text { disorder, and } \\
\text { delusional } \\
\text { disorder }\end{array}$ & $\begin{array}{l}\text { HDL, TG, cortisol, } \\
\text { and DHEA-S }\end{array}$ & & $\begin{array}{l}\text { (working memory, RBANS) in the } \\
\text { group of patients but not in controls. }\end{array}$ \\
\hline $\begin{array}{l}\text { Nugent } \\
\text { et al. (32) }\end{array}$ & $30(17 / 13)$ & $32.6 \pm 12.1$ & $20(12 / 8)$ & $35.7 \pm 12.8$ & SCZ & $\begin{array}{l}\text { SBP, DBP, HR, } \\
\text { BMI, WHR, HDL, } \\
\text { TC, HbA1c, CRP, } \\
\text { urine epinephrine } \\
\text { and } \\
\text { norepinephrine, } \\
\text { urine cortisol, and } \\
\text { blood DHEA }\end{array}$ & $\begin{array}{l}\text { SCID, BPRS, } \\
\text { UPSA-2, and } \\
\text { PSS }\end{array}$ & $\begin{array}{l}\text { The AL index was significantly higher } \\
\text { in patients. Higher AL index was } \\
\text { associated with more severe positive } \\
\text { symptoms (BPRS) and functional } \\
\text { impairment (UPSA-2). Perceived } \\
\text { stress (PSS) was not related to the } \\
\text { AL index neither in patients nor in } \\
\text { controls. }\end{array}$ \\
\hline $\begin{array}{l}\text { Piotrowski } \\
\text { et al. (33) }\end{array}$ & $\begin{array}{c}42 \text { FEP } \\
\text { patients } \\
(21 / 21) \\
25 \text { SCZ } \\
\text { patients } \\
(14 / 11) \\
37 \text { FHR-P } \\
\text { individuals } \\
(12 / 25)\end{array}$ & $\begin{array}{l}\text { FEP patients: } \\
27.7 \pm 7.3 \text { SCZ: } \\
42.8 \pm 13.8 \\
\text { FHR-P: } 36.9 \pm \\
11.0\end{array}$ & $\begin{array}{c}42 \\
(16 / 26)\end{array}$ & $27.8 \pm 8.4$ & $\begin{array}{l}\text { FEP, SCZ, and } \\
\text { FHR-P } \\
\text { (unaffected } \\
\text { offspring of SCZ } \\
\text { patients) }\end{array}$ & $\begin{array}{l}\text { SBP, DBP, BMI, } \\
\text { WHR, CRP, } \\
\text { fibrinogen, } \\
\text { albumin, glucose, } \\
\text { insulin, TC, LDL, } \\
\text { HDL, TG, cortisol, } \\
\text { and DHEA-S }\end{array}$ & $\begin{array}{l}\text { OPCRIT, } \\
\text { PANSS, SANS, } \\
\text { SAPS, HDRS, } \\
\text { YMRS, RBANS, } \\
\text { GAF, SOFAS, } \\
\text { LTE, and PSS }\end{array}$ & $\begin{array}{l}\text { The AL index was significantly higher } \\
\text { in patients with psychosis and FHR- } \\
\text { P individuals compared to HCs. } \\
\text { Patients with FEP and FHR-P } \\
\text { individuals had similar AL index. } \\
\text { Moreover, the AL index was } \\
\text { significantly higher in SCZ-AR } \\
\text { patients compared to other groups } \\
\text { of participants. Higher AL index was } \\
\text { associated with more severe general } \\
\text { psychopathology and depressive } \\
\text { symptoms, lower scores of attention } \\
\text { and semantic fluency, as well as } \\
\text { worse general functioning in patients } \\
\text { with psychosis. There was a } \\
\text { significant negative correlation } \\
\text { between the AL index and the } \\
\text { scores of attention in FHR-P } \\
\text { individuals. }\end{array}$ \\
\hline $\begin{array}{l}\text { Savransky } \\
\text { et al. (34) }\end{array}$ & $44(28 / 16)$ & $32.7 \pm 12.6$ & $\begin{array}{c}33 \\
(19 / 14)\end{array}$ & $35.3 \pm 14.2$ & $\begin{array}{l}\text { SCZ and } \\
\text { schizoaffective } \\
\text { disorder }\end{array}$ & $\begin{array}{l}\text { SBP, DBP, HR, } \\
\text { BMI, WHR, HDL, } \\
\text { TC, HbA1c, CRP, } \\
\text { urine epinephrine } \\
\text { and } \\
\text { norepinephrine, } \\
\text { urine cortisol, and } \\
\text { blood DHEA }\end{array}$ & SCID and BPRS & $\begin{array}{l}\text { The AL index was significantly higher } \\
\text { in the group of patients compared to } \\
\text { controls. The AL index was } \\
\text { significantly and inversely associated } \\
\text { with fractional anisotropy of the } \\
\text { fornix in both groups. }\end{array}$ \\
\hline $\begin{array}{l}\text { Savransky } \\
\text { et al. (35) }\end{array}$ & $58(41 / 17)$ & $36.1 \pm 14.3$ & $\begin{array}{c}34(20 / \\
14)\end{array}$ & $35.3 \pm 14.0$ & $\begin{array}{c}\text { SCZ and } \\
\text { schizoaffective } \\
\text { disorder }\end{array}$ & $\begin{array}{l}\text { SBP, DBP, HR, } \\
\text { BMI, WHR, HDL, } \\
\text { TC, HbA1c, CRP, } \\
\text { urine epinephrine } \\
\text { and } \\
\text { norepinephrine, } \\
\text { urine cortisol, and } \\
\text { blood DHEA }\end{array}$ & SCID and BPRS & $\begin{array}{l}\text { The AL index was significantly higher } \\
\text { in early psychosis patients and those } \\
\text { with chronic illness compared to } \\
\text { controls. Higher AL index was } \\
\text { associated with more severe positive } \\
\text { symptoms in patients with early } \\
\text { psychosis. }\end{array}$ \\
\hline
\end{tabular}

AL, allostatic load; BPRS, the Brief Psychiatric Rating Scale (36), CAARMS, the Comprehensive Assessment of At-Risk Mental States (37); CGI, the Clinical Global Impression Scale (38); CISS, the Coping Inventory for Stressful Situations (39); CRP, C-reactive protein; DBP, diastolic blood pressure; DHEA, dehydroepiandrosterone; DHEA-S, dehydroepiandrosterone sulfate; FEP, first-episode psychosis; FHR-P, individuals at familial high risk of psychosis; GAF, the Global Assessment of Functioning (40); GF-R, the Global Functioning Role Scale (41); GF-S, the Global Functioning Social Scale (41); HbA1c, glycosylated hemoglobin; HDL, high-density lipoproteins; HDRS, the Hamilton Depression Rating Scale (42); IL, interleukin; LDL, low-density lipoproteins; LTE, the List of Threatening Experiences (43); OPCRIT, the Operational Criteria for Psychotic IIIness Checklist (44); PANSS, the Positive and Negative Syndrome Scale (45); PSS, the Perceived Stress Scale (46); SANS, the Scale for the Assessment of Negative Symptoms (47); SAPS, the Scale for the Assessment of Positive Symptoms (47); SBP, systolic blood pressure; SCID, the Structured Clinical Interview for DSM-IV; SCZ, schizophrenia; SOFAS, the Social and Occupational Functioning Assessment Scale (48); TC, total cholesterol; TG, triglycerides; TNF- $\alpha$, tumor necrosis factor- $\alpha$; UHR, ultra-high risk of psychosis; WHR, waist-to-hip ratio; YMRS, the Young Mania Rating Scale (49).

patients with schizophrenia $(29,34)$. Chiappelli et al. (29) found significantly lower average cortical thickness in patients with schizophrenia compared to controls. This difference appeared to be insignificant after accounting for the $\mathrm{AL}$ index. More specifically, higher diastolic blood pressure and heart rate as well as elevated levels of urine norepinephrine and CRP predicted reductions of cortical thickness in the group of patients. In healthy controls, only BMI and CRP levels were associated with cortical thickness. Another study examined the relationship between the AL index and white matter connectivity 
(29). The authors found that higher AL index was associated with lower fornix structural connectivity in patients with schizophrenia and healthy controls. There were also some correlation between the AL index and structural connectivity of internal capsule, corona radiata, thalamic radiation, sagittal striatum, and superior longitudinal fasciculus in patients with schizophrenia. However, these correlations were insignificant after correction for multiple testing.

\section{SUMMARY OF EVIDENCE AND FUTURE DIRECTIONS}

Convincing evidence indicates systemic biological dysregulations associated with stress exposure in patients with psychotic disorders that occurs in the early course of illness. Elevated AL index might be related to more severe positive symptoms and functional impairment in psychosis. Although it has been reported that the AL index decreases in the course of antipsychotic treatment (27), it still remains elevated in patients with chronic schizophrenia $(32,33)$. The mechanisms of these alterations remain unknown. One scenario is that experiencing acute psychotic symptoms might itself trigger a number of biological responses. However, the AL index remains elevated in outpatients with schizophrenia (32). Our group revealed that decreased use of active coping strategies contribute to elevated AL index via the effects of depressive symptoms (30).

Less is known about the effects of stress on the AL index. Three studies revealed that recent stressors are unlikely to account for increased AL index in FEP patients and schizophrenia outpatients $(30,32,33)$. Our group also found no association between lifetime stressors and the AL index in FEP patients (33). However, the list of threatening experiences (43) provides a limited insight into life stressors. A history of childhood trauma is a well-established risk factor of psychosis (5). Moreover, poor infant psychosocial environment has been associated with physiological dysregulations that can be conceptualized in frame of the AL concept (50). Therefore, investigating the effects of childhood trauma on the AL index serves as one of directions for future studies. Given that early-life stress is neither necessary nor sufficient to trigger the onset of psychosis as approximately one third of patients with psychosis report this type of experiences, insights into potential mediators and moderators should be taken into account $(4,6)$. Indeed, a number of psychological phenomena have been found to mediate the effects of traumatic events on psychosis risk, including cognitive biases and self disturbances (51, 52). Childhood adversities have been associated with increased AL index in adult non-clinical populations $(53,54)$; however, a mediating effect of social support has been reported (54). A lack of association between the measures of psychosocial stress and the AL index in previous studies of patients with psychosis might also imply that stress is not a primary mechanism of elevated AL index in this group of patients. Instead, physiological dysregulations captured by the AL index might result from processes that are inherent to the pathophysiology of psychosis. This scenario is supported by recent findings showing similar AL index in patients with FEP and FHR-P individuals (33). Moreover, reconsidering the definition of stressors might provide further insights into the mechanisms of elevated $\mathrm{AL}$ index in psychosis. Indeed, McEwen and Wingfield $(24,55)$ posited that other stressors, including infections, injuries or nutritional deficiencies may also contribute to allostatic overload.

Although a number of studies revealed increased AL index in patients with psychosis, causal inference cannot be established due to a cross-sectional design. However, indirect evidence suggests that stress response measured as the AL index might contribute to a number of neurostructural alterations that are typical for patients with schizophrenia, including reduced cortical thickness and white matter connectivity $(29,34)$. In agreement with these findings, we found that increased AL might account for working memory deficits (measured by the digit span task) observed in FEP patients (31). There were no significant correlations between working memory performance and the $\mathrm{AL}$ index in healthy controls. Working memory deficits are widely observed in patients with schizophrenia and bipolar disorder, and are more closely related to psychosis dimension than a diagnostic group itself $(56,57)$. Prefrontal cortex that represents one of main neural substrates of working memory contains a high density of glucocorticoid receptors (58). It has been shown that acute stress at high loads might impact working memory (59). In support of our results, a recent study by Reed et al. (60), revealed that the Trier Social Stress Test disrupted accuracy during the working memory task in chronic schizophrenia patients, but not in healthy controls. These findings suggest that patients with psychotic disorders and healthy controls might be differentially vulnerable to the effects of stress responses.

Investigating the $\mathrm{AL}$ concept in patients with psychotic disorders might also improve our understanding of the mechanisms underlying epigenetic alterations. Indeed, psychotic disorders are also characterized by a number of epigenetic alterations, especially differential DNA methylation, with some concordant patterns in the brain and peripheral tissues $(61,62)$. Our group also revealed that a history of childhood trauma might be associated with lower methylation of LINE-1 sequences, representing surrogate measures of global DNA methylation (14). There is also consistent evidence that a history of childhood trauma might be associated with global DNA hypomethylation and reduced expression of the BDNF gene in patients with psychosis (63). One of directions for future studies would be to test the mediating role of allostatic mechanisms in gene $x$ environment interactions. One of candidate genes would be the FKBP5, encoding the FK506 binding protein, which acts as a co-chaperone for glucocorticoid receptors (64). Indeed, it has consistently been shown that variations in the FKBP5 gene interact with early life stress and influence several outcomes of psychotic disorders [for review see (2)]. Moreover, allele-specific demethylation of the FKBP5 gene has been found to mediate gene $\times$ childhood trauma 
interactions (65). Finally, a recent study by Lee et al. (66) demonstrated that blood FKBP5 methylation and mRNA expression levels might be a marker of 30-day cortisol load.

It should be noted that there is no consensus regarding a calculation of the AL index and inclusion of specific markers. This inconsistency might explain differences regarding correlates of elevated AL index in patients with psychosis. To date, there are two main approaches of calculating the AL index-the one based on percentiles in healthy controls and the second one referring to conventional clinical thresholds. The use of thresholds established in the general population seems to be more relevant for clinical practice; however, it may underestimate subclinical physiological dysregulations widely observed at early stages of psychosis. Moreover, certain biomarkers, e.g., cytokines or BDNF, do not have established norms. In turn, the use of percentiles established in healthy controls, although widely implemented in previous studies of the AL concept, requires representative cohorts and appropriate matching of patients and healthy controls. Although several studies based on non-clinical populations revealed that the AL index better predicts morbidity and mortality, compared to traditional detection methods and single markers employed in biomedical practice (26), its clinical value for patients with psychosis remains unknown. At this point, it should be noted that the AL concept shares some similarity with other composite predictors, including metabolic syndrome and the Framingham Risk Score (67). However, it has been shown that the AL index is conceptually different and better predicts unfavorable health outcomes than metabolic syndrome $(68,69)$. This is particularly important since life expectancy is reduced up to 20 years in patients with psychosis, mostly due to high prevalence of metabolic syndrome and cardiovascular diseases $(70,71,72)$. A consensus panel of $\mathrm{AL}$ mediators would enable to tailor early intervention aimed at reducing cardiovascular risk in psychotic disorders. In addition, repeated measures of the AL index would support monitoring the efficacy

\section{REFERENCES}

1. Perala J, Suvisaari J, Saarni SI, Kuoppasalmi K, Isometsa E, Pirkola S, et al. Lifetime prevalence of psychotic and bipolar I disorders in a general population. Arch Gen Psychiatry (2007) 64:19-28. doi: 10.1001/archpsyc. 64.1.19

2. Misiak B, Stramecki F, Gawęda Ł, Prochwicz K, Sąsiadek MM, Moustafa $\mathrm{AA}$, et al. Interactions Between Variation in Candidate Genes and Environmental Factors in the Etiology of Schizophrenia and Bipolar Disorder: a Systematic Review. Mol Neurobiol (2017) 55:5075-100. doi: 10.1007/s12035-017-0708-y

3. Marín O. Developmental timing and critical windows for the treatment of psychiatric disorders. Nat Med (2016) 22:1229-38. doi: 10.1038/nm.4225

4. Bonoldi I, Simeone E, Rocchetti M, Codjoe L, Rossi G, Gambi F, et al. Prevalence of self-reported childhood abuse in psychosis: A meta-analysis of retrospective studies. Psychiatry Res (2013) 210:8-15. doi: 10.1016/ j.psychres.2013.05.003

5. Varese F, Smeets F, Drukker M, Lieverse R, Lataster T, Viechtbauer W, et al. Childhood adversities increase the risk of psychosis: A meta-analysis of patient-control, prospective-and cross-sectional cohort studies. Schizophr Bull (2012) 38:661-71. doi: 10.1093/schbul/sbs050 of pharmacotherapy and psychotherapy. Before implementation to clinical practice, longitudinal studies are required to investigate the effects of antipsychotics on the AL index. This is particularly important for antipsychotics that are known to be effective in terms of improving symptomatic outcomes but lead to the development of several metabolic side effects. Differentiating between the effects of antipsychotics on the AL index driven by their efficacy and those related to metabolic adversities is needed.

In summary, the AL concept holds a great promise for understanding the role of stress in the pathophysiology of psychotic disorders. Longitudinal studies of at risk populations, with a range of clinical data, are needed to disentangle dynamics and causal mechanisms of detrimental effects associated with stress exposure in psychosis. Resilience and vulnerability factors should be taken into account to understand differential effects of stress exposure in various populations. A consensus statement regarding the measurement of the $\mathrm{AL}$ in psychiatric research is needed to enable comparability and generalization of results from future studies as well as translation of predictive models into clinical practice.

\section{AUTHOR CONTRIBUTIONS}

BM confirms being the sole contributor of this work and has approved it for publication.

\section{FUNDING}

This work was funded from science budget resources granted for the years 2016-2019 (the Iuventus Plus grant awarded by the Ministry of Science and Higher Education, grant number: IP2015 052474).
6. Misiak B, Krefft M, Bielawski T, Moustafa AA, Sąsiadek MM, Frydecka D. Toward a unified theory of childhood trauma and psychosis: A comprehensive review of epidemiological, clinical, neuropsychological and biological findings. Neurosci Biobehav Rev (2017) 75:393-406. doi: 10.1016/ j.neubiorev.2017.02.015

7. Girshkin L, Matheson SL, Shepherd AM, Green MJ. Morning cortisol levels in schizophrenia and bipolar disorder: A meta-analysis. Psychoneuroendocrinology (2014) 49:187-206. doi: 10.1016/j.psyneuen.2014. 07.013

8. Mondelli V, Pariante CM, Navari S, Aas M, D'Albenzio A, Di Forti M, et al. Higher cortisol levels are associated with smaller left hippocampal volume in first-episode psychosis. Schizophr Res (2010) 119:75-8. doi: 10.1016/ j.schres.2009.12.021

9. Day FL, Valmaggia LR, Mondelli V, Papadopoulos A, Papadopoulos I, Pariante CM, et al. Blunted Cortisol Awakening Response in People at Ultra High Risk of Developing Psychosis. Schizophr Res (2014) 158:25-31. doi: 10.1016/j.schres.2014.06.041

10. Ciufolini S, Dazzan P, Kempton MJ, Pariante C, Mondelli V. HPA axis response to social stress is attenuated in schizophrenia but normal in depression: evidence from a meta-analysis of existing studies. Neurosci Biobehav Rev (2014) 47:359-68. doi: 10.1016/j.neubiorev.2014.09.004 
11. Theleritis C, Fisher HL, Shäfer I, Winters L, Stahl D, Morgan C, et al. Brain derived neurotropic factor (BDNF) is associated with childhood abuse but not cognitive domains in first episode psychosis. Schizophr Res (2014) 159:56-61. doi: 10.1016/j.schres.2014.07.013

12. Di Nicola M, Cattaneo A, Hepgul N, Di Forti M, Aitchison KJ, Janiri L, et al. Serum and gene expression profile of cytokines in first-episode psychosis. Brain Behav Immun (2013) 31:90-5. doi: 10.1016/j.bbi.2012.06.010

13. Misiak B, Kiejna A, Frydecka D. The history of childhood trauma is associated with lipid disturbances and blood pressure in adult first-episode schizophrenia patients. Gen Hosp Psychiatry (2015) 37:365-7. doi: 10.1016/j.genhosppsych. 2015.03.017

14. Misiak B, Szmida E, Karpiński P, Loska O, Sąsiadek MM, Frydecka D. Lower LINE-1 methylation in first-episode schizophrenia patients with the history of childhood trauma. Epigenomics (2015) 7:1275-85. doi: 10.2217/epi.15.68

15. Alameda L, Ferrari C, Baumann PS, Gholam-Rezaee M, Do KQ, Conus P. Childhood sexual and physical abuse: Age at exposure modulates impact on functional outcome in early psychosis patients. Psychol Med (2015) 45:272736. doi: $10.1017 /$ S0033291715000690

16. Misiak B, Frydecka D. A history of childhood trauma and response to treatment with antipsychotics in first-episode schizophrenia patients. J Nerv Ment Dis (2016) 204:787-92. doi: 10.1097/NMD.0000000000000567.

17. Labad J, Stojanovic-Pérez A, Montalvo I, Solé M, Cabezas Á, Ortega L, et al. Stress biomarkers as predictors of transition to psychosis in at-risk mental states: Roles for cortisol, prolactin and albumin. J Psychiatr Res (2015) 60:1639. doi: 10.1016/j.jpsychires.2014.10.011

18. Romero LM, Dickens MJ, Cyr NE. The reactive scope model - A new model integrating homeostasis, allostasis, and stress. Horm Behav (2009) 55:375-89. doi: 10.1016/j.yhbeh.2008.12.009

19. Del Giudice M, Ellis BJ, Shirtcliff EA. The Adaptive Calibration Model of stress responsivity. Neurosci Biobehav Rev (2011) 35:1562-92. doi: 10.1016/ j.neubiorev.2010.11.007

20. Walker EF, Diforio D. Schizophrenia: A Neural Diathesis-Stress Model. Psychol Rev (1997) 104:667-85. doi: 10.1037/0033-295X.104.4.667

21. Misiak B, Frydecka D, Zawadzki M, Krefft M, Kiejna A. Refining and integrating schizophrenia pathophysiology - Relevance of the allostatic load concept. Neurosci Biobehav Rev (2014) 45:183-201. doi: 10.1016/j.neubiorev. 2014.06.004

22. Sterling P, Eyer J. Allostasis: a new paradigm to explain arousal pathology. In: Fisher S, Reason JT, editors. Handbook of Life Stress, Cognition, and Health. (John Wiley \& Sons: Oxford) (1988). p. 629-49.

23. McEwen BS. Protective and damaging effects of stress mediators: Central role of the brain. Dialogues Clin Neurosci (2006) 8:367-81. doi: 10.1056/ NEJM199801153380307

24. McEwen BS, Wingfield JC. The concept of allostasis in biology and biomedicine. Horm Behav (2003) 43:2-15. doi: 10.1016/S0018-506X(02) 00024-7

25. McEwen BS. Allostasis and the epigenetics of brain and body health over the life course: The brain on stress. JAMA Psychiatry (2017) 74:551-2. doi: 10.1001/jamapsychiatry.2017.0270

26. Juster RP, McEwen BS, Lupien SJ. Allostatic load biomarkers of chronic stress and impact on health and cognition. Neurosci Biobehav Rev (2010) 35:2-16. doi: 10.1016/j.neubiorev.2009.10.002

27. Berger M, Juster R-P, Westphal S, Amminger GP, Bogerts B, Schiltz K, et al. Allostatic load is associated with psychotic symptoms and decreases with antipsychotic treatment in patients with schizophrenia and first-episode psychosis. Psychoneuroendocrinology (2018) 90:35-42. doi: 10.1016/ j.psyneuen.2018.02.001

28. Berger M, Lavoie S, McGorry PD, Nelson B, Markulev C, Yuen HP, et al. Relationship between allostatic load and clinical outcomes in youth at ultrahigh risk for psychosis in the NEURAPRO study. Schizophr Res (2018). doi: 10.1016/j.schres.2018.10.002

29. Chiappelli J, Kochunov P, Savransky A, Fisseha F, Wisner K, Du X, et al. Allostatic load and reduced cortical thickness in schizophrenia. Psychoneuroendocrinology (2017) 77:105-11. doi: 10.1016/j.psyneuen.2016. 11.021

30. Misiak B, Kotowicz K, Loska O, Stramecki F, Beszłej JA, Samochowiec J, et al. Decreased use of active coping styles contributes to elevated allostatic load index in first-episode psychosis. Psychoneuroendocrinology (2018) 96:166-72. doi: 10.1016/j.psyneuen.2018.06.021

31. Misiak B, Kotowicz K, Loska O, Stramecki F, Beszłej JA, Samochowiec J, et al. Elevated allostatic load index is associated with working memory deficits in first-episode psychosis. Schizophr Res (2018) 204:439-41.

32. Nugent KL, Chiappelli J, Rowland LM, Hong LE. Cumulative stress pathophysiology in schizophrenia as indexed by allostatic load Psychoneuroendocrinology (2015) 60:120-9. doi: 10.1016/j.psyneuen.2015. 06.009

33. Piotrowski P, Kotowicz K, Rymaszewska J, Beszłej JA, Plichta P, Samochowiec J, et al. Allostatic load index and its clinical correlates at various stages of psychosis. Schizophr Res (2019) 210:73-80. doi: 10.1016/ j.schres.2019.06.009

34. Savransky A, Chiappelli J, Rowland LM, Wisner K, Shukla DK, Kochunov P, et al. Fornix Structural Connectivity and Allostatic Load: Empirical Evidence From Schizophrenia Patients and Healthy Controls. Psychosom Med (2017) 79:770-6. doi: 10.1097/PSY.0000000000000487

35. Savransky A, Chiappelli J, Fisseha F, Wisner K, Xiaomin D, Mirmomen SM, et al. Elevated allostatic load early in the course of schizophrenia. Transl Psychiatry (2018) 8:246. doi: 10.1038/s41398-018-0299-z

36. Overall JE, Gorham DR. The Brief Psychiatric Rating Scale. Psychol Rep (1962) 10:799-812. doi: 10.2466/pr0.1962.10.3.799

37. Yung AR, Yuen HP, McGorry PD, Phillips LJ, Kelly D, Dell'Olio M, et al. Mapping the onset of psychosis: The Comprehensive Assessment of At-Risk Mental States. Aust N Z J Psychiatry (2005) 39:964-71. doi: 10.1111/j.14401614.2005.01714.x

38. Busner J, Targum SD. The clinical global impressions scale: applying a research tool in clinical practice. Psychiatry (2007) 4:28-37. doi: 10.1371/ journal.pone. 0144146

39. Endler NS, Parker JDA. Multidimensional Assessment of Coping: A Critical Evaluation. J Pers Soc Psychol (1990) 58:844-54. doi: 10.1037/00223514.58.5.844

40. Hall RCW. Global Assessment of Functioning. Psychosomatics (1995) 36:26775. doi: 10.1016/S0033-3182(95)71666-8

41. Cornblatt BA, Auther AM, Niendam T, Smith CW, Zinberg J, Bearden CE, et al. Preliminary findings for two new measures of social and role functioning in the prodromal phase of schizophrenia. Schizophr Bull (2007) 33:688-702. doi: 10.1093/schbul/sbm029

42. Hamilton M. A rating scale for depression. J Neurol Neurosurg Psychiatry (1960) 23:56-62. doi: 10.1136/jnnp.23.1.56

43. Brugha TS, Cragg D. The list of threatening experiences: the reliability and validity of a brief life events questionnaire. Acta Psychiatr Scand (1990) 82:7781. doi: 10.1111/j.1600-0447.1990.tb01360.x

44. McGuffin P. A polydiagnostic application of operational criteria in studies of psychotic illness. Arch Gen Psychiatry (1991) 48:764. doi: 10.1001/ archpsyc.1991.01810320088015

45. Kay SR, Fiszbein A, Opler LA. The positive and negative syndrome scale (PANSS) for schizophrenia. Schizophr Bull (1987) 13:261-76. doi: 10.1093/ SCHBUL/13.2.261

46. Cohen S, Kamarck T, Mermelstein R. A global measure of perceived stress. J Health Soc Behav (1983) 24:385-96. doi: 10.2307/2136404

47. Andreasen NC. Methods for assessing positive and negative symptoms. Mod Probl Pharmacopsychiatry (1990) 24:73-88.

48. Goldman HH, Skodol AE, Lave TR. Revising axis V for DSM-IV: A review of measures of social functioning. Am J Psychiatry (1992) 149:1148-56. doi: 10.1176/ajp.149.9.1148

49. Young RC, Biggs JT, Ziegler VE, Meyer DA. A rating scale for mania: reliability, validity and sensitivity. Br J Psychiatry J Ment Sci (2011) 133:429-35. doi: 10.1192/bjp.133.5.429

50. Doom JR, Reid BM, Blanco E, Burrows R, Lozoff B, Gahagan S. Infant psychosocial environment predicts adolescent cardiometabolic risk: a prospective study. J Pediatr (2019) 209:85-91. doi: 10.1016/ j.jpeds.2019.01.058

51. Gaweda T, Prochwicz K, Adamczyk P, Frydecka D, Misiak B, Kotowicz K, et al. The role of self-disturbances and cognitive biases in the relationship between traumatic life events and psychosis proneness in a non-clinical sample. Schizophr Res (2017) 193:218-24. doi: 10.1016/j.schres.2017.07.023 
52. Gawęda L, Pionke R, Krężołek M, Prochwicz K, Kłosowska J, Frydecka D, et al. Self-disturbances, cognitive biases and insecure attachment as mechanisms of the relationship between traumatic life events and psychotic-like experiences in non-clinical adults - A path analysis. Psychiatry Res (2018) 259:571-8. doi: 10.1016/j.psychres.2017.11.009

53. Groër MW, Kostas-Polston EA, Dillahunt-Aspillaga C, Beckie TM, JohnsonMallard V, Duffy A, et al. Allostatic Perspectives in Women Veterans With a History of Childhood Sexual Assault. Biol Res Nurs (2016) 18:454-64. doi: $10.1177 / 1099800416638442$

54. Horan JM, Widom CS. From Childhood Maltreatment to Allostatic Load in Adulthood: The Role of Social Support. Child Maltreat (2015) 20:229-39. doi: $10.1177 / 1077559515597063$

55. McEwen BS, Wingfield JC. What is in a name? Integrating homeostasis, allostasis and stress. Horm Behav (2010) 57:105-11. doi: 10.1016/ j.yhbeh.2009.09.011

56. Frydecka D, Eissa AM, Hewedi DH, Ali M, Drapała J, Misiak B, et al. Impairments of working memory in schizophrenia and bipolar disorder: The effect of history of psychotic symptoms and different aspects of cognitive task demands. Front Behav Neurosci (2014) 8:416. doi: 10.3389/ fnbeh.2014.00416

57. Simonsen C, Sundet K, Vaskinn A, Birkenaes AB, Engh JA, Færden A, et al. Neurocognitive dysfunction in bipolar and schizophrenia spectrum disorders depends on history of psychosis rather than diagnostic group. Schizophr Bull (2011) 37:73-83. doi: 10.1093/schbul/sbp034

58. Lupien SJ, McEwen BS. The acute effects of corticosteroids on cognition: Integration of animal and human model studies. Brain Res Rev (1997) 24:127. doi: 10.1016/S0165-0173(97)00004-0

59. Oei NYL, Everaerd WTAM, Elzinga BM, Van Well S, Bermond B. Psychosocial stress impairs working memory at high loads: An association with cortisol levels and memory retrieval. Stress (2006) 9:133-41. doi: 10.1080/10253890600965773

60. Reed A, Lake J, Hamilton H, Bachman P, Clayson P, Miller G, et al. Cortisol Response to Psychosocial Stress and Working Memory Performance in Schizophrenia. Schizophr Bull (2017) 43:41. doi: 10.1093/schbul/sbx021.109

61. Van Den Oord EJCG, Clark SL, Xie LY, Shabalin AA, Dozmorov MG, Kumar G, et al. A whole methylome CpG-SNP association study of psychosis in blood and brain tissue. Schizophr Bull (2016) 42:1018-26. doi: $10.1093 /$ schbul/sbv182

62. Misiak B, Frydecka D, Piotrowski P, Kiejna A. The multidimensional nature of metabolic syndrome in schizophrenia: Lessons from studies of one-carbon metabolism and DNA methylation. Epigenomics (2013) 5:317-29. doi: 10.2217/epi.13.22

63. Tomassi S, Tosato S. Epigenetics and gene expression profile in first-episode psychosis: The role of childhood trauma. Neurosci Biobehav Rev (2017) 83:226-37. doi: 10.1016/j.neubiorev.2017.10.018
64. Binder EB. The role of FKBP5, a co-chaperone of the glucocorticoid receptor in the pathogenesis and therapy of affective and anxiety disorders. Psychoneuroendocrinology (2009) 34:S186-195. doi: 10.1016/ j.psyneuen.2009.05.021

65. Klengel T, Mehta D, Anacker C, Rex-Haffner M, Pruessner JC, Pariante $\mathrm{CM}$, et al. Allele-specific FKBP5 DNA demethylation mediates genechildhood trauma interactions. Nat Neurosci (2013) 16:33-41. doi: 10.1038/ nn. 3275

66. Lee RS, Mahon PB, Zandi PP, McCaul ME, Yang X, Bali U, et al. DNA methylation and sex-specific expression of FKBP5 as correlates of one-month bedtime cortisol levels in healthy individuals. Psychoneuroendocrinology (2018) 97:164-73. doi: 10.1016/j.psyneuen.2018.07.003

67. Gallo LC, Fortmann AL, Mattei J. Allostatic load and the assessment of cumulative biological risk in biobehavioral medicine: Challenges and opportunities. Psychosom Med (2014) 76:478-80. doi: 10.1097/ PSY.0000000000000095

68. Karlamangla AS, Singer BH, McEwen BS, Rowe JW, Seeman TE. Allostatic load as a predictor of functional decline: MacArthur studies of successful aging. J Clin Epidemiol (2002) 55:696-710. doi: 10.1016/S0895-4356(02) 00399-2

69. Mattei J, Demissie S, Falcon LM, Ordovas JM, Tucker K. Allostatic load is associated with chronic conditions in the Boston Puerto Rican Health Study. Soc Sci Med (2010) 70:1988-96. doi: 10.1016/j.socscimed.2010.02.024

70. Laursen TM, Munk-Olsen T, Gasse C. Chronic somatic comorbidity and excess mortality due to natural causes in persons with schizophrenia or bipolar affective disorder. PloS One (2011) 6:e24597. doi: 10.1371/ journal.pone.0024597

71. Piotrowski P, Gondek TM, Królicka-Deręgowska A, Misiak B, Adamowski T, Kiejna A. Causes of mortality in schizophrenia: An updated review of European studies. Psychiatr Danub (2017) 29:108-20. doi: 10.24869/psyd. 2017.108

72. McCaffery JM, Marsland AL, Strohacker K, Muldoon MF, Manuck SB. Factor Structure Underlying Components of Allostatic Load. PloS One (2012) 7: e47246. doi: 10.1371/journal.pone.0047246

Conflict of Interest: The author declares that the research was conducted in the absence of any commercial or financial relationships that could be construed as a potential conflict of interest.

Copyright (c) 2020 Misiak. This is an open-access article distributed under the terms of the Creative Commons Attribution License (CC BY). The use, distribution or reproduction in other forums is permitted, provided the original author(s) and the copyright owner(s) are credited and that the original publication in this journal is cited, in accordance with accepted academic practice. No use, distribution or reproduction is permitted which does not comply with these terms. 